\title{
Aerobic treatment of winery wastewater with the aim of water reuse
}

\author{
M. Oliveira, C. Queda and E. Duarte
}

\begin{abstract}
An air micro-bubble bioreactor (AMBB) using a free self-adapted microbial population, $15 \mathrm{dm}^{3}$ working volume, was used for aerobic treatment of winery wastewater. This reactor utilizes a Venturi injector in conjunction with mass transfer multiplier nozzles, which allow an efficient oxygen transfer. The reactor can operate in batch or continuous conditions. The dynamics of chemical oxygen demand (COD), biomass and total contents of polyphenolic compounds was followed throughout each trial. The wastewater COD ranged between $4.0-8.0 \mathrm{~kg} \mathrm{COD} \mathrm{m}^{-3}$ and the efficiency of the batch treatment was about $90.0 \pm 4.3 \%$, after 6 days of operation. The maximum efficiency obtained was achieved after 15 days of treatment (99\%).

In continuous conditions, the loading rate and the treatment efficiency ranged between $0.45-1.00 \mathrm{~kg} \mathrm{COD} \mathrm{m}^{-3} \mathrm{~d}^{-1}$ and $93.3 \pm 2.0 \%$, respectively. The AMBB hydraulic retention time was 15 days. To assess the suitability of treated water in relation to vineyard irrigation, the effluent was physico-chemical analysed and direct toxicity bioassays with effluent matrix were carried out using Lepidium sativum L. seeds. The results showed the water quality required to be reutilised minimizing water consumption. This study will contribute for the implementation of an efficient water use plan, aiming the preservation of the water resource and the reduction of the wastewater production.
\end{abstract}

Key words | aerobic biological treatment, phytotoxicity, water supply, winery wastewater

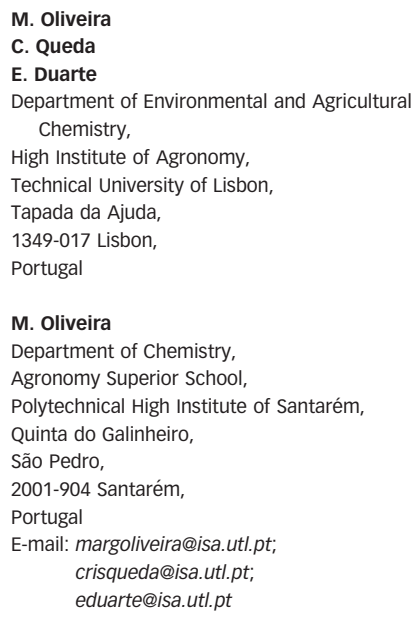

\section{INTRODUCTION}

The winery wastewater is seasonally produced and its treatment represents a main problem to the winery sector, as a result of the amount and composition of the effluent produced over the year. Winery wastewater is generated mainly as the result of washing equipment and bottles and purges from the cooling process. As a consequence of the working period and the winemaking technologies, volumes and pollution loads greatly vary over the year (Duarte et al. 2004; Eusébio et al. 2005). Consequently, the treatment system must be versatile to face both the loading regimen and stream fluctuation. Further, as each winery is unique in wastewater generation (highly variable, 2 to $14 \mathrm{~L}$ per litre of wine) and disposal, plans for doi: $10.2166 /$ wst.2009.558 environmentally friendly management of waste are not universal and should be tested for its effectiveness. In Portugal, many wineries discharge their wastewater into rivers without treatment, only $17 \%$ of the wineries have environmental licence, 5\% dispose a pre-treated wastewater for the municipal wastewater treatment and $7 \%$ dispose the treated wastewater into water body (MAOTDR 2007). On the other hand, most wineries are not able to identify the efficiency of the treatment system. Therefore, the disposal of winery wastewater is one of the main environmental problems related to wine industries.

Several winery wastewater treatments are available, but the development of alternative technologies is essential to 
increase their efficiency and to decrease the investment and exploration costs. The most promising treatment system appears to be the vertical aerobic reactors characterised by good oxygen transfer and high biological conversion capacity (Petruccioli et al. 2000). To optimise the mass transfer, a highly efficient venturi injector coupled with multiplier nozzles (AirJection ${ }^{\circledR}$ ) was applied in lagoon (Meyer et al. 2004).

In order to achieve the best available technology is also important to be acquainted with the wastewater final disposal. There is increasing interest in treated wastewater as a source of supplemental irrigation (Ryder \& Chrobak 2004). In water scarce regions, there is a benefit when the treated wastewater is used as an economic additional water supply, in agriculture. Therefore, a number of concerns had to be taken into account and the knowledge of the treated wastewater composition is critical for safe use (Bustamante et al. 2005). However, chemical analysis could be insufficient to provide the potential ecological risk, since they do not allow an evaluation of possible combined effects of the different contaminants mixed together, as well as their bioavailability. Bioassays, which can mitigate these constraints, are, therefore, recommended for the assessment of ecological risks in soils or other matrices to be used as organic amendments (van Gestel et al. 20oI; Fjällborg et al. 2005).

The main objective of this study was to evaluate a winery wastewater treatment system based on an air microbubble bioreactor (AMBB) at a bench-scale, and also to assess the suitability of treated water in relation to vineyard irrigation.

\section{MATERIAL AND METHODS}

\section{Wastewater characterization}

The winery wastewater was collected, between September 2006 and August 2008, from the Casa Agrícola Quinta da Casa Boa, located at Runa, Portugal, from a winery only producing red wines. The selected winery has a small/ medium dimension with a production capacity of 200,000 L. Composite samples of the winery wastewater, representative of each phase of the process, were taken and maintained at $4^{\circ} \mathrm{C}$. A set of major key parameters were defined and analysed, according to Standard Methods for the Examination of Water and Wastewater (1998), in order to assess the winery wastewater pollutant charge: $\mathrm{pH}$, conductivity, chemical oxygen demand (COD), biochemical oxygen demand (BOD), total suspended solids (TSS), volatile suspended solids (VSS), phenols, surfactants, $\mathrm{Na}, \mathrm{K}, \mathrm{Mg}$ and $\mathrm{Ca}$. The winery wastewater flow was evaluated from water consumption. With this propose the winery installed general water counters to be daily read and register.

\section{Bioreactor equipment}

The AMBB with a total volume of $15 \mathrm{dm}^{3}$ consists of a cylindrical bioreactor, equipped with a circulated pump, a high efficiency Venturi injector (HEVI) in conjunction with mass transfer multiplier nozzles (MTM) and a settler. The MTM nozzles discharge the air/water mixture from the HEVI into the bottom of the bioreactor. The flow diagram of the AMBB is shown in Figure 1.

\section{Start up and operating conditions of AMBB}

Four trails performed with the AMBB, under batch conditions were carried out during 15 days. The reactor was inoculated with $15 \mathrm{dm}^{3}$ of fresh winery wastewater, from the vintage period and with $0.15 \mathrm{dm}^{3}$ of acclimated

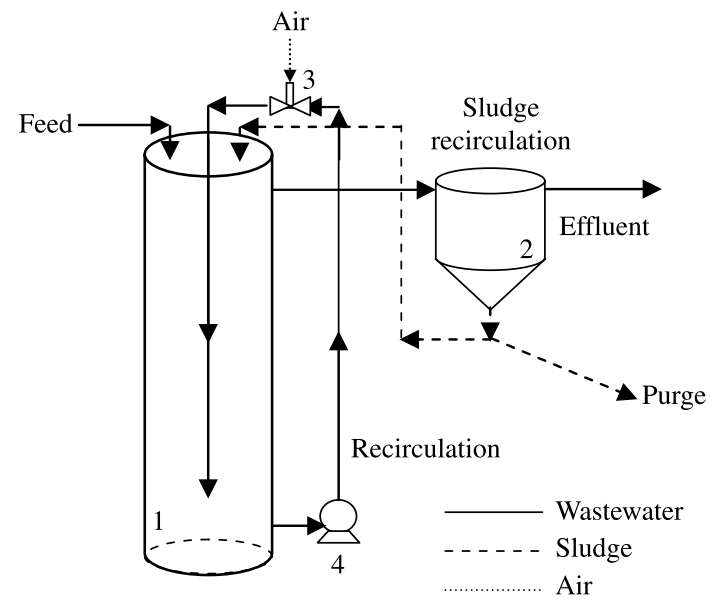

Figure 1 | Flow diagram of the air micro-bubble bioreactor. 1-Bioreactor; 2-Settler; 3-Venturi injector; 4-Recirculation pump. 
biomass, previously obtained from a winery aerobic reactor. Samples from the mixed liquor were daily taken for physico-chemical characterization. During the continuous conditions, the AMBB started with fresh winery wastewater, from the vintage period, implemented with $4 \mathrm{~g}$ of urea to balance the nutrient requirements and no biomass was inoculated. The AMBB was fed continuously with a feeding rate ranging between $0.45-1.00 \mathrm{~kg} \mathrm{COD} \mathrm{m}^{-3}$ day $^{-1}$. The hydraulic and the solid retention time were 15 days and 40 days, respectively. The recirculation of the mixed liquor was $20 \mathrm{minhour}^{-1}$, with a flow of $40 \mathrm{dm}^{3} \mathrm{~min}^{-1}$. The aerated flow was $2 \mathrm{dm}^{3} \mathrm{~min}^{-1}$. The operating temperature was $20-30^{\circ} \mathrm{C}$.

\section{Seed germination bioassays}

Germination tests were performed following Fuentes $e t$ al. (2004), by using cress Lepidium sativum L. seeds. The treated wastewater and two dilutions in distilled water $(25 \%, 50 \% \mathrm{v} / \mathrm{v})$ were tested. An aliquot of $3 \mathrm{~mL}$ of each dilution was disposed onto a filter paper (Whatman $\left.n^{\circ} 1\right)$ contained in a Petri dish ( $90 \mathrm{~mm}$ diam.). Distilled water was used as control. Five replicates of 10 seeds per plate and per dilution were tested. After $48 \mathrm{~h}$ of incubation at $20 \pm 2^{\circ} \mathrm{C}$ in the dark, seed germination rate and the root length were measured. Germination index (GI), expressed in percentage, was calculated as $\mathrm{GI}=(\mathrm{RSG} \times \mathrm{RRG}) / 100$ (Zucconi et al. 1985), where RSG represents the relative seed germination and RRG the relative root growth, after exposure to the treated wastewater. All experiments were repeated twice. The data of cress seed germination bioassays were subjected to analysis of variance (ANOVA) and the means compared by the Tukey's test at a 5\% significance level.

\section{RESULTS AND DISCUSSION}

\section{Wastewater qualitative assessment}

During the studying period, samples of winery wastewater were taken for laboratory characterization to evaluate their pollutant charge (Table 1). The values of $\mathrm{pH}$ ranged from 4 to 8 , being this variation mostly dependent on the labor period. The electric conductivity of the wastewater showed no relevant variation in the different sampling periods and the range of registered values is not considered as inhibiting biomass growth.

The highest values of COD were reached during the vintage period, followed by the first racking. These results are in accordance to those previously reported by other authors (Petruccioli et al. 2002). As expected, the highest values of biodegradability $\left(\mathrm{BOD}_{5} / \mathrm{COD}\right)$ were achieved during the vintage period (Figure 2), due to the high concentration of simple molecules, easily metabolized (sugars and ethanol) by microorganisms (Duarte et al. 2004).

Concerning TS and TSS parameters, the results reveal a high variability during the vinification period. Moreover, the TS are significantly higher than TSS, which means that these wastewaters contain, mostly, dissolved organic pollutant charge.

Table 1 Physical and chemical characterization of the wastewater

\begin{tabular}{lllll} 
Parameter & $\begin{array}{l}\text { Labor period } \\
\text { Vintage }\end{array}$ & 1st racking & 2nd racking & Bottling \\
\hline $\mathrm{pH}$ & $5-7$ & $4-8$ & 5 & 8 \\
Conductivity $\left(\mu \mathrm{S} \mathrm{cm}^{-1}\right)$ & $1,885-2,110$ & $1,145-2,260$ & $2,030-2,400$ & 1,265 \\
$\mathrm{COD}\left(\mathrm{mg} \mathrm{L}^{-1}\right)$ & $5,360-10,170$ & $4,460-7,260$ & $1,580-5,930$ & 1,805 \\
$\mathrm{BOD}_{5}\left(\mathrm{mg} \mathrm{L}^{-1}\right)$ & $1,770-8,085$ & $2,250-4,360$ & $250-900$ & 580 \\
$\mathrm{TS}\left(\mathrm{mg} \mathrm{L}^{-1}\right)$ & $2,160-10,270$ & $2,555-3,210$ & $2,170-4,470$ & 2,200 \\
$\mathrm{TSS}\left(\mathrm{mg} \mathrm{L}^{-1}\right)$ & $340-550$ & $730-1,010$ & $160-2,060$ & 185 \\
Surfactants $\left(\mathrm{mg} \mathrm{L}^{-1}\right)$ & $10-30$ & $4-20$ & $3-7$ & 2 \\
Phenolic compounds $\left(\mathrm{mg} \mathrm{L}^{-1}\right)$ & $6-32$ & $20-35$ & $5-29$ & 2 \\
\hline
\end{tabular}




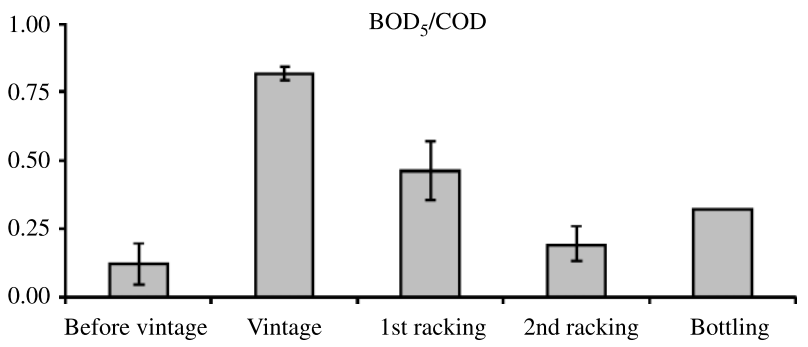

Figure 2 | Biodegradability indicators of the winery wastewater, in different labour periods. Bars represent standard deviation.

Although phenols and anionic surfactants are important pollutants, it is not expected that they could influence the organic load, since they are present in low concentration.

\section{AMBB treatment}

The bioreactor AMBB was tested in the vintage period and during racking. The evolution of COD concentration, biomass and polyphenolic compounds was followed, during the different periods and no significant differences were obtained (Figure 3a). Regarding the biomass evolution, a typical growth curve for batch cultivation was achieved (Figure 3b). This curve does not show a lag phase, since biomass was already adapted.

The winery wastewater COD ranged between $4.0-8.0 \mathrm{kgCOD} \mathrm{m}^{-3}$ and the efficiency of the batch treatment was about $90.0 \pm 4.3 \%$, after 6 days of operation. This period is related to the biomass exponential phase. The maximum efficiency obtained (98.6 $\pm 0.4 \%)$ was achieved after 15 days of treatment. In these conditions, the polyphenols dynamic was also evaluated. The results showed a similar behavior between COD and polyphenolic compounds (Figure 3a). The winery wastewater polyphenols ranged between $4.5-10 \mathrm{~g} \mathrm{~m}^{-3}$ and the removal efficiency during the batch treatment was about $80.4 \pm 9.3 \%$, after 6 days of operation. For polyphenols, the maximum efficiency was $94.2 \pm 3.7 \%$, after 15 days of treatment (Figure 3b). These results are comparable with those reported by Beltran de Herédia et al. (2005), where they achieve $75 \%$ and $50 \%$ of COD and polyphenols reduction, respectively, after 3 days of treatment. In the present work, the COD reduction was lower, but the efficiency of polyphenolic compounds removal was about $60 \%$.

During the continuous process, the bioreactor started with a loading rate of $0.45 \mathrm{kgCOD} \mathrm{m}^{-3} \mathrm{day}^{-1}$, a feed-tomicroorganisms ratio $(\mathrm{F} / \mathrm{M})$ of $0.20 \mathrm{~kg}_{\mathrm{COD}} \mathrm{kg}_{\mathrm{MVLSS}}^{-1} \mathrm{day}^{-1}$ and a sludge retention time of 40 days. After a start up period of 40 days (Figure 4), required for the microbial flora adaptation, the MLSS was about $3.5 \mathrm{~kg} \mathrm{~m}^{-3}$. The observed yield coefficient for biomass growth $\left(Y_{\mathrm{obs}}\right)$ was quite low, $0.09 \mathrm{~kg}_{\text {MLVss }} \mathrm{kg}_{\mathrm{COD}}^{-1}$. Despite of the quite low sludge production, the bioreactor showed an effluent organic load of $0.30 \pm 0.04 \mathrm{~kg}_{\mathrm{COD}} \mathrm{m}^{-3}$, thus account for a COD removal higher than 93\%. The obtained results are comparable to those reported by other authors (Petruccioli et al. 2002; Eusébio et al. 2005), with the advantage of the low sludge production. Similar results are reported by Brucculeri et al. (2005) and Racault \& Stricker (2004), which stated that both the high sludge retention time and the high biodegradability of the substrates enlighten the low observed yields.
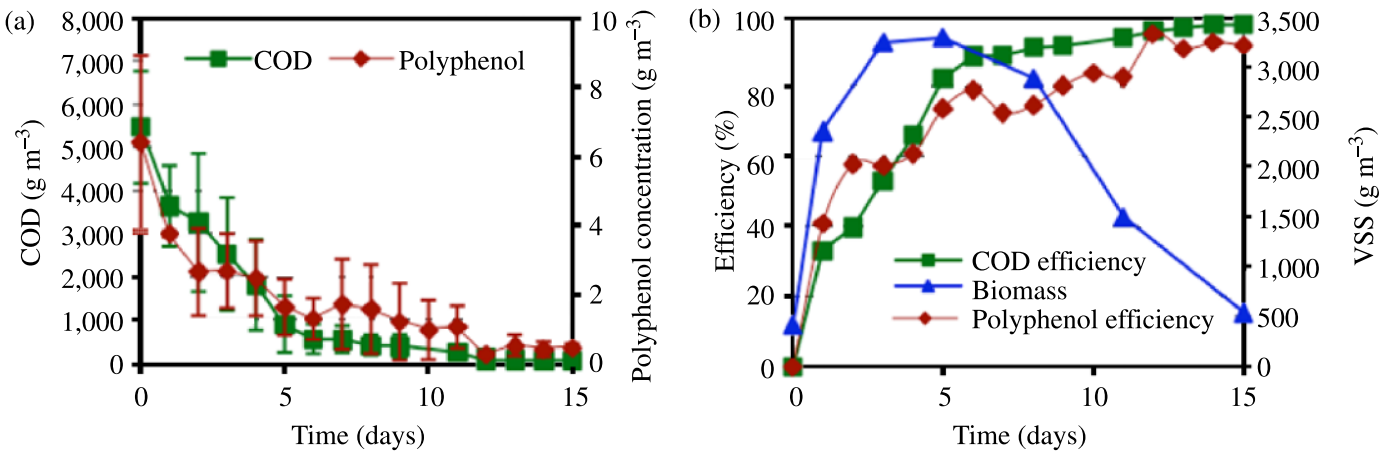

Figure 3 | (a) Evolution of COD and polyphenol concentration means, in the AMBB; bars represent standard deviation; (b) Reduction efficiency of COD, polyphenol and biomass concentration in the AMBB. 


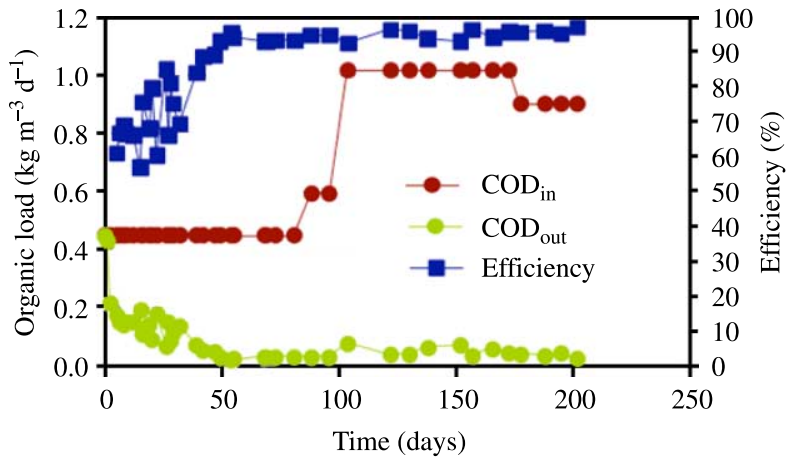

Figure 4 Evolution of the air microbubble bioreactor (AMBB) performance, assessed by chemical oxygen demand (COD) removal efficiency.

In order to assess the loading rate influence on the AMBB performance, the initial conditions were changed. The loading rate was increased to $1.00 \mathrm{~kg}_{\mathrm{COD}} \mathrm{m}^{-3} \mathrm{day}^{-1}$, the $\mathrm{F} / \mathrm{M}$ ratio was about $0.27 \mathrm{~kg}_{\mathrm{COD}} \mathrm{kg}_{\mathrm{MLVSs}}^{-1} \mathrm{day}^{-1}$ and the observed yield coefficient for biomass growth was $0.13 \mathrm{~kg}_{\text {MLVSS }} \mathrm{kg}_{\mathrm{COD}}^{-1}$. In these conditions the COD removal efficiency achieves $96 \pm 3 \%$. Despite the higher loading rate of the wastewater, the treatment efficiency increased, without a significant variation of biomass growth. This unexpected result could be explained by the highest specific oxygen respiration rate of biomass, originated by a higher $\mathrm{F} / \mathrm{M}$ ratio (Brucculeri et al. 2005), thus revealing a good adaptation of the microbial population (data not shown) to high organic loads.

The AMBB effluent was physico-chemical characterized in order to evaluate its suitability to be used in crop

Table 2 | Physical and chemical characterization of the treated wastewater and standard parameters for water irrigation use

\begin{tabular}{lll} 
Parameter & Treated wastewater & DL n'236/98 \\
\hline $\mathrm{pH}$ & $7.7-8.8$ & $4.5-9.0$ \\
Conductivity $\left(\mu \mathrm{S} \mathrm{cm}^{-1}\right)$ & $750-1,050$ & - \\
$\mathrm{COD}\left(\mathrm{mg} \mathrm{L}^{-1}\right)$ & $40-200$ & - \\
$\mathrm{N}$ total $\left(\mathrm{mg} \mathrm{L}^{-1}\right)$ & 2.0 & - \\
$\mathrm{P}$ total $\left(\mathrm{mg} \mathrm{L}^{-1}\right)$ & 0.6 & - \\
Phenolic compounds $\left(\mathrm{mg} \mathrm{L}^{-1}\right)$ & $0.4-0.6$ & - \\
$\mathrm{TSS}^{\circ}\left(\mathrm{mg} \mathrm{L}^{-1}\right)$ & $10-60$ & 60 \\
$\mathrm{Cl}^{-}\left(\mathrm{mg} \mathrm{L}^{-1}\right)$ & $60-70$ & 70 \\
$\mathrm{SO}_{4}^{2-}\left(\mathrm{mg} \mathrm{L}^{-1}\right)$ & $50-60$ & 575 \\
$\mathrm{SAR}^{-1}$ & 27 & 8 \\
\hline
\end{tabular}

irrigation (Table 2). All the analyzed parameters except one were in accordance with EU and Portuguese Legislation (Directive 2000/60/EC, DL n ${ }^{\circ}$ 236/98) for irrigation use. Of particular concern was the sodium adsorption ratio (SAR), the proportion of sodium to calcium and magnesium, which was higher than the permitted parametric value. However, this treated wastewater will be used in irrigation systems to supplement irrigation water, as an economic additional water supply. The aim of water reutilization is to minimize water consumption. Nevertheless, other management strategies could be established in the celery, to diminish the SAR ratio.

\section{Seed germination bioassays}

Seed germination assays were developed for evaluating the effects of water contaminants on germination and seedling growth. Significant inhibition of this development phase will influence the capacity of plants to compete and survive in their environment (Standard Methods for the Examination of Water and Wastewater 1998). The adequacy of the treated wastewater for crop irrigation was evaluated with direct toxicity bioassays, by using cress seeds as indicator. These bioassays were carried out for undiluted and diluted treated wastewater. No significant differences $(P=0.05)$ between batch experiments were registered on GI (Figure 5). The undiluted wastewater was responsible by a significant decrease of the GI, as compared to diluted wastewater, when both batches were considered. No significant interaction (batch $x$ dilution) was recorded.

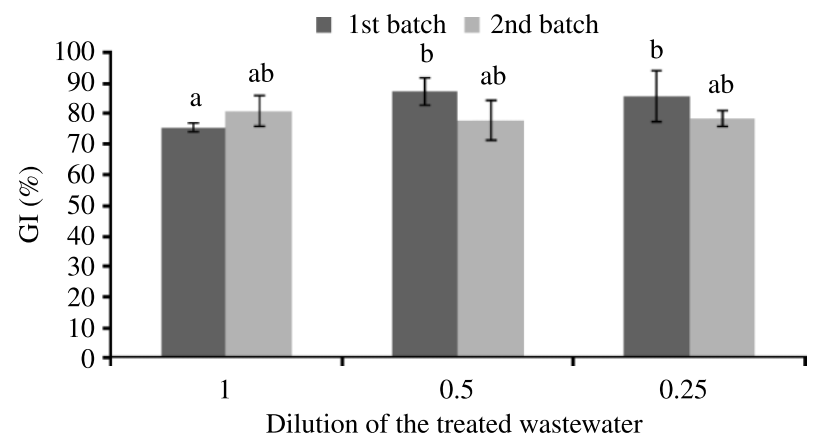

Figure 5 Germination Index (\%) of cress seeds exposed to different dilutions of treated wastewater. Columns marked with the same letter are not statistically different $(P=0.05)$, according to Tukey's test. 
As the cress bioassay is a standard procedure to evaluate the behaviour of crops to water contaminants, data evidence the suitability of treated wastewater in relation to crop irrigation, thus minimizing water consumption. While the quantity of wastewater available will account for only a small fraction of the total irrigation water requirements, these wastewaters could be used as additional water supply.

\section{CONCLUSIONS}

The AMBB performance in batch conditions shows a good COD removal, after 6 days of treatment. These results allow the evaluation of this reactor during start-ups, which is essential for seasonal wastewaters. During continuous process, the AMBB reveals a COD efficiency of $93.3 \pm 2.0 \%$, which showed to be not dependent on the applied loading pollutant charge, of the feeding effluent. In these conditions the biomass demonstrates a low conversion degree, quantified by the observed yield coefficient for biomass growth (0.090.13 $\left.\mathrm{kg}_{\text {MLVSS }} \mathrm{kg}_{\mathrm{COD}}^{-1}\right)$.

The treated wastewater revealed its suitability to be integrated in the irrigation systems as confirmed by direct toxicity bioassays and physico-chemical characteristics. These results are promising and the system will be optimized in what concerns hydraulic retention time; oxygen transfer and contact time, energetic costs and sludge production. These will contribute to the settlement of the AMBB treatment at the Pilot-scale.

\section{ACKNOWLEDGEMENTS}

Fundação para a Ciência e a Tecnologia (FCT) - PhD grant SFRH/BD/31653/2006.

\section{REFERENCES}

Beltran de Herédia, J., Torregrosa, J., Dominguez, J. R. \& Partido, E. 2005 Degradation of wine distillery wastewaters by the combination of aerobic biological treatment with chemical by Fenton's reagent. Water Sci. Technol. 51(1), 167-174.

Brucculeri, M., Bolzonella, D., Battistoni, P., and Cecchi, F. 2005 Treatment of mixed municipal and winery wastewaters in convencional actived sludge process: A case study. Water Sci. Technol. 51(1), 89-98.

Bustamante, M. A., Paredes, C., Moral, R., Moreno-Caselles, J., Pérez-Espinosa, A., and Pérez-Murcia, M. D. 2005 Uses of winery and distillery effluents in agriculture: Characterisation of nutrients and hazardous components. Water Sci. Technol. 51(1), 145-151.

Duarte, E., Reis, I. B. \& Martins, M. 2004 Implementation of an environmental management plan towards the global quality concept-A challenge to the winery sector. In: Proceedings of the 3rd International Specialised Conference on Sustainable Viticulture and Winery Wastes Management, Barcelona, 23-30.

Eusébio, A., Mateus, M., Baeta-Hall, L., Almeida-Vara, E. \& Duarte, J. C. 2005 Microflora evaluation of two agro-industrial effluents treated by the JACTO jet-loop type reactor system. Water Sci. Technol. 51(1), 107-112.

Fjällborg, B., Ahlberg, G., Nilsson, E. \& Dave, G. 2005 Identification of metal toxicity in sewage sludge leachate. Environ. Int. 31(1), 25-31.

Fuentes, A., Lloréns, M., Sáez, J., Aguilar, M. I., Ortuño, J. F. \& Meseguer, V. F. 2004 Phytotoxicity and heavy metals speciation of stabilized sewage sludges. J. Hazard. Mater. 108(3), 161-169.

MAOTDR-Ministério do Ambiente, do Ordenamento do Território e do Desenvolvimento Regional 2007 Estratégia Nacional para os Efluentes Agro-Pecuários e AgroIndustriais-ENEAPAI. Ed. Ministério do Ambiente, do Ordenamento do Território e do Desenvolvimento Regional, ENEAPAI, Lisboa, p. 174.

Meyer, R. M., Mazzei, A. L. \& Mullin, J. R. 2004 Aerobic treatment of winery wastewater utilizing new aeration technology. In: Proceedings of the 3rd International Specialised Conference on Sustainable Viticulture and Winery Wastes Management, Barcelona, 353-355.

Petruccioli, M., Duarte, J. C. \& Federici, F. 2000 High-rate aerobic treatment of winery wastewater using bioreactors with free and immobilized activated sludge. J. Biosci. Bioeng. 90(4), 381-386.

Petruccioli, M., Duarte, J. C., Eusébio, A. \& Federici, F. 2002 Aerobic treatment of winery wastewater using a jet-loop activated sludge reactor. Process Biochem. 37(8), 821-829.

Racault, Y. \& Stricker, A. E. 2004 Combining membrane filtration and aerated storage: assessment of two full scale processes treating winery effluents. In: Proceedings of the 3rd International Specialised Conference on Sustainable Viticulture and Winery Wastes Management, Barcelona, $105-112$.

Ryder, R. A. \& Chrobak, R. S. 2004 Water quality considerations in the use of domestic wastewater effluents in vineyard irrigation. In: Proceedings of the 3rd International Specialised Conference on Sustainable Viticulture and Winery Wastes Management, Barcelona, 307-308.

Standard Methods for the Examination of Water and Wastewater 1998 20th edition, American Public Health Association/ 
American Water Works Association/Water Environment Federation, Washington, DC, USA.

van Gestel, C. A. M., van der Waarde, J. J., Derksen, J. G. M., van der Hoek, E. E., Veul, M. F. X. W., Bouwens, S., Rusch, B., Kronenburg, R. \& Stokman, G. N. M. 20oI The use of acute and chronic bioassays to determine the ecological risk and bioremediation efficiency of oil-polluted soils. Environ. Toxicol. Chem. 20(7), 1438-1449.

Zucconi, F., Monaco, A., Forte, M. \& Bertoldi, M. D. 1985 Phytotoxins during the stabilization of organic matter. In: Gasser, J. K. R. (ed.) Composting of Agricultural and Other Wastes. Elsevier, London, pp. 73-85. 
Copyright of Water Science \& Technology is the property of IWA Publishing and its content may not be copied or emailed to multiple sites or posted to a listserv without the copyright holder's express written permission. However, users may print, download, or email articles for individual use. 